\title{
Sedimentary pigments and organic carbon in relation to microalgal and benthic faunal abundance in the Gulf of Carpentaria
}

\author{
Michele A. Burford, Brian G. Long, Peter C. Rothlisberg \\ CSIRO Marine Laboratories, PO Box 120, Cleveland, Queensland 4163, Australia
}

\begin{abstract}
Sediment samples were collected at 105 sites throughout the Gulf of Carpentaria, Australia, in November-December 1990. Highest concentrations of chlorophyll a in the sediment occurred in 3 regions: the southeast, the northeast and the western Gulf. Fucoxanthin, the pigment indicative of diatoms and prymnesiophytes, was present at most sites. Astaxanthin, present in microcrustaceans, was most highly concentrated in the same areas as chlorophyll a. The concentration of organic carbon was highest in the northwest and decreased towards the southeast, and was correlated with an increase in sediment grain size. Correlation analyses of pigments, environmental parameters and macrobenthos indicated relationships between individual pigments, and between pigments, molluscs, polychaetes, crustaceans and depth. When the variation due to sediment grain size was statistically controlled for, organic carbon was found to be a poor indicator of biological factors in the sediment.
\end{abstract}

KEY WORDS: Sediment - Pigments - Microalgae - Macrobenthos

\section{INTRODUCTION}

The Gulf of Carpentaria, Australia, is a large $(3.7 \times$ $\left.10^{5} \mathrm{~km}^{2}\right)$, shallow $(<70 \mathrm{~m})$, tropical $\left(11\right.$ to $\left.17.5^{\circ} \mathrm{S}\right)$ embayment that supports a substantial commercial, multi-species prawn fishery and has the potential to support demersal and pelagic finfish fisheries. The Gulf is reputed to be a highly productive shallow tropical sea (Motoda et al. 1978, Rothlisberg \& Jackson 1982). Motoda et al. (1978) found that the chlorophyll a standing stock and primary productivity in the northern Gulf in summer were high relative to values found throughout the world [mean $=32.7 \mathrm{mg} \mathrm{m}^{-2}(\mathrm{n}=6)$ and mean $=1395.6 \mathrm{mg} \mathrm{C} \mathrm{m}^{-2} \mathrm{~d}^{-1}(\mathrm{n}=7)$ respectively]. Rothlisberg et al. (in press) measured the in situ ${ }^{14} \mathrm{C}$ primary productivity at 9 stations in February 1988 and found somewhat lower values (mean $=914 \mathrm{mg} \mathrm{C} \mathrm{m}^{-2} \mathrm{~d}^{-1}$ ). Rothlisberg \& Jackson (1982) measured the zooplankton standing stocks with both fine and coarse mesh nets $(142$ and $500 \mu \mathrm{m})$ and found the biomasses were seasonally variable (1.4 to $2.4 \mathrm{~g} \mathrm{~m}^{-2}, 142 \mu \mathrm{m} ; 0.5$ to $\left.1.0 \mathrm{~g} \mathrm{~m}^{-2}, 500 \mu \mathrm{m}\right)$ but were comparable with other highly productive seas. None of these studies, how- ever, has compared the standing stocks or productivities of the water column with those of the benthos.

Pigments such as chlorophylls and carotenoids are useful indicators of algal biomass and chemotaxonomic markers of mixed phytoplankton populations (Gieskes et al. 1988, Rowan 1989, Everitt et al. 1990). In marine sediments, pigments originate primarily from benthic microalgae, phytoplankton detritus, faecal pellets and infaunal benthos. The use of high performance liquid chromatography (HPLC) for separating and quantifying pigments has improved the accuracy of quantitative analysis of individual pigments and their breakdown products (e.g. Wright \& Shearer 1984). This is the first attempt at using this technique in a large-scale study of the benthic community, and is of particular importance in sediments, since chlorophylls and carotenoids derived from phytoplankton detritus and faecal pellets are in a degraded form (Daemen 1986, Repeta \& Gagosian 1987, Abele-Oeschger 1991). Since pigments are subject to differential rates of degradation (Abele-Oeschger 1991), caution should be exercised in attempting to quantify the contribution of algal groups to the detritus and faecal pellet biomass. 
Organic carbon in sediments is an indicator of biological processes in the water column and within the sediment. Its distribution has been correlated with water depth, grain size, terrestrial runoff and hydrography and generally relates to the patterns of pelagic primary production (for review see Alongi 1990). There is usually a decrease in organic carbon with depth across continental shelves and down the continental slope, which has historically been attributed to decreased primary production in the overlying water column.

The aims of this study were to examine the distribution of sediment pigments in the Gulf of Carpentaria in relation to physical aspects of the environment, such as sediment grain size and depth. The role of benthic microalgae and phytoplankton detritus in providing a food source for the macrobenthos is also examined by relating pigment distribution and abundance to macrobenthos abundance and biomass, and organic carbon.

\section{METHODS}

Three replicate $0.1 \mathrm{~m}^{2}$ Smith-McIntyre grab samples were taken at 105 stations systematically throughout the Gulf of Carpentaria in November-December 1990 to identify and count the macrobenthos and to deter-

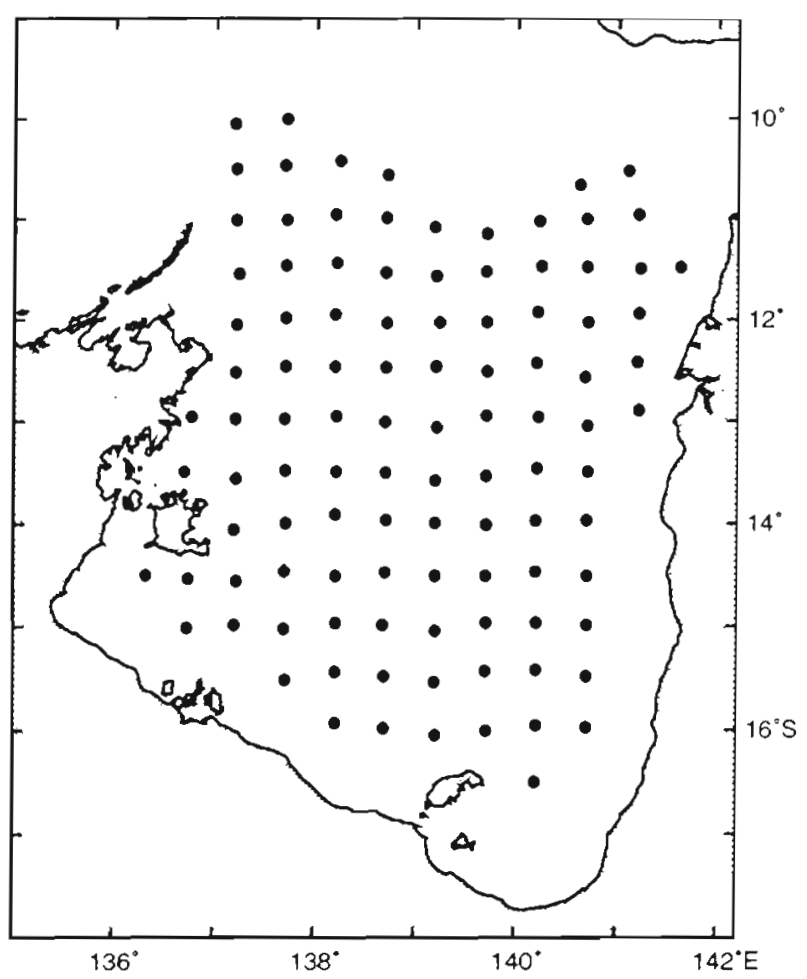

Fig. 1. Location of 105 sites sampled for sediment in the Gulf of Carpentaria, Australia, during November-December 1990 mine the grain size and pigments of the sediment (Fig. 1). The contents of each grab were emptied into a tray with 1 and $2 \mathrm{~mm}$ mesh sieves. All benthos greater than $1 \mathrm{~mm}$ were sorted from each grab (Long \& Poiner in press). Benthos less than $1 \mathrm{~mm}$ were not sorted. A subsample of approximately $500 \mathrm{~g}$ was taken from the top $5 \mathrm{~cm}$ of the first grab at each site for pigment, organic carbon and grain size analysis. Samples were immediately frozen at $-20^{\circ} \mathrm{C}$ until analysed. Sediment samples were sorted into 9 fractions which were grouped as mud $(<0.63 \mu \mathrm{m})$, sand $(0.63 \mu \mathrm{m}$ to $2.0 \mathrm{~mm})$ and gravel ( $>2.0 \mathrm{~mm}$ ) (Somers \& Long in press).

Pigment and organic carbon analyses were done in the laboratory within 3 mo of the cruise. Two samples of 1 to $2 \mathrm{~g}$ were chipped from the frozen sediment sample, one for pigment analysis, the other for organic carbon analysis. Dry weights of sediment subsamples were obtained after oven-drying at $60^{\circ} \mathrm{C}$ for $24 \mathrm{~h}$.

Pigment analysis. Each sample was ultra-sonicated with a Branson microtip probe for $1 \mathrm{~min}$ in $100 \%$ cold methanol. Samples were filtered through a $0.2 \mu \mathrm{m}$ nylon filter and injected into an HPLC system. Samples with low concentrations of pigments were concentrated by partitioning into diethyl ether, evaporation and redissolving in methanol, prior to injection into the HPLC system. The solvent system, a modification of Gieskes \& Kraay (1983), consisted of 2 solvent mixtures: (A) 30\% water in methanol, and (B) 20\% ethyl acetate in methanol. These solvents were pumped in a linear gradient from $20 \%$ to $100 \%$ of solvent B in $30 \mathrm{~min}$, followed by $10 \mathrm{~min}$ in $100 \%$ solvent $\mathrm{B}$. The solvents were run through a $3.9 \times 150 \mathrm{~mm}$ RP-C18 column

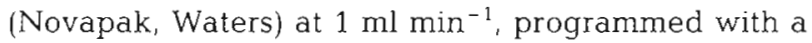
system controller (Waters Model 720). Absorbance was measured with a detector (Waters Model 440) at $436 \mathrm{~nm}$. The detector was attached to an integrator (Hewlett Packard 3394A), which automatically integrated peak areas. A flow-through cell in a spectrophotometer (Hitachi U-2000) was used to detect peaks at $665 \mathrm{~nm}$. Peaks were identified by collecting them from the HPLC, evaporating the solvent and then redissolving the fractions in ethanol. The absorption spectra of the major peaks was obtained with a spectrophotometer (Hitachi U-2000).

The spectra and HPLC retention times of the various pigments (see Fig. 2) were compared with absorption and chromatographic characteristics of pigments isolated from cultures of Phaeodactylum tricornutum (Bacillariophyceae $=$ diatoms), Pavlova lutheri $($ Prymnesiophyceae = golden brown flagellates), Dunaliella tertiolecta (Chlorophyceae $=$ green algae), Amphidinium carterae (Dinophyceae = dinoflagellates), Chroomonas salina (Cryptophyceae $=$ cryptophytes), Phaeocystis pouchetii (Chrysophyceae $=$ chrysophytes $)$ and Oscilla toria sp. (Cyanobacteria) maintained in our laboratory. 


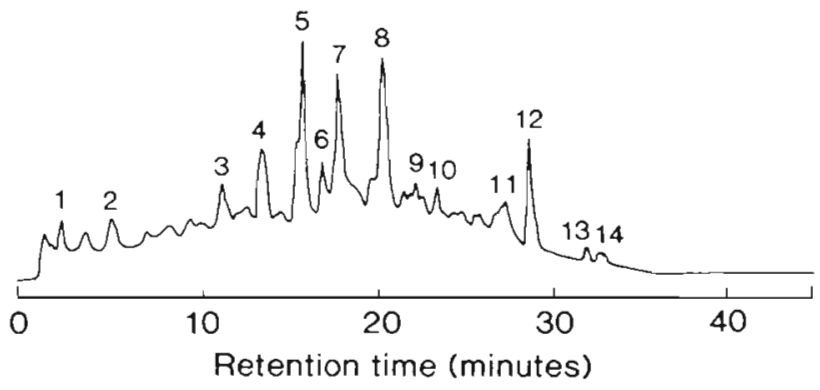

Fig. 2. High performance liquid chromatogram of pigment extract of sediment sample from the Gulf of Carpentaria, Australia, at $436 \mathrm{~nm}$. Peak identifications: 1,2 = chlorophyll related; $3=$ phaeophorbide $a_{;} 4=$ chlorophyllide $a_{i} 5=$ fucoxanthin; $6=$ unidentified; $7=$ phaeophorbide and violaxanthin; $8=$ astaxanthin and esters; $9=$ astaxanthin and esters; 10,11 . $12=$ unidentified $; 13,14=$ chlorophyll $a$

Pigments were also identified by comparison with published maxima of absorption spectra (Rowan 1989).

Chlorophyll standards (Sigma) were used to estimate concentrations of chlorophyll $a$ and chlorophyll $b$. Concentrations of carotenoid pigments were calculated from extinction coefficients given in Rowan (1989). An astaxanthin standard was supplied by Hoffman LaRoche AG (Basel).

Fucoxanthin was used as the indicator pigment for diatoms, prymnesiophytes and chrysophytes (Wright \& Jeffrey 1987. Stauber \& Jeffrey 1988). The pigment, astaxanthin and its esters, are often present in demersal and infaunal microcrustaceans (Castillo et al. 1982, Repeta \& Gagosian 1987). Astaxanthin and its esters eluted as a major and a minor peak (Fig. 2).

This study focuses on the major pigments present in the Gulf of Carpentaria. Other pigments were identified, however due to their low concentrations, the results are not presented. The microalgal biomass is expressed as concentration of pigment in the sediment $\left(\mu \mathrm{g} \mathrm{kg}^{-1}\right)$, and an estimate of the microcrustacean biomass is expressed as the concentration of astaxanthin in the sediment $\left(\mu \mathrm{g} \mathrm{kg}^{-1}\right)$.

Organic carbon analysis. Dried samples were analysed for organic carbon content after they were ground in a hammer mill (Culatti) for between 15 and 30 s until the sample passed through a $1 \mathrm{~mm}$ sieve. The samples were heated, oxidised with potassium dichromate and sulphuric acid, and then titrated with ferrous ammonium sulphate solution (Gaudette et al. 1974). Results were expressed as the concentration of organic carbon in the sediment $\left(\mathrm{g} \mathrm{kg}^{-1}\right)$.

Correlation analysis. A Pearson's correlation matrix of environmental variables and pigment variables, and macrobenthos and pigment variables was constructed with SAS statistical software. Pigment results were square-root-transformed, and macrobenthos biomasses were log-transformed and abundances

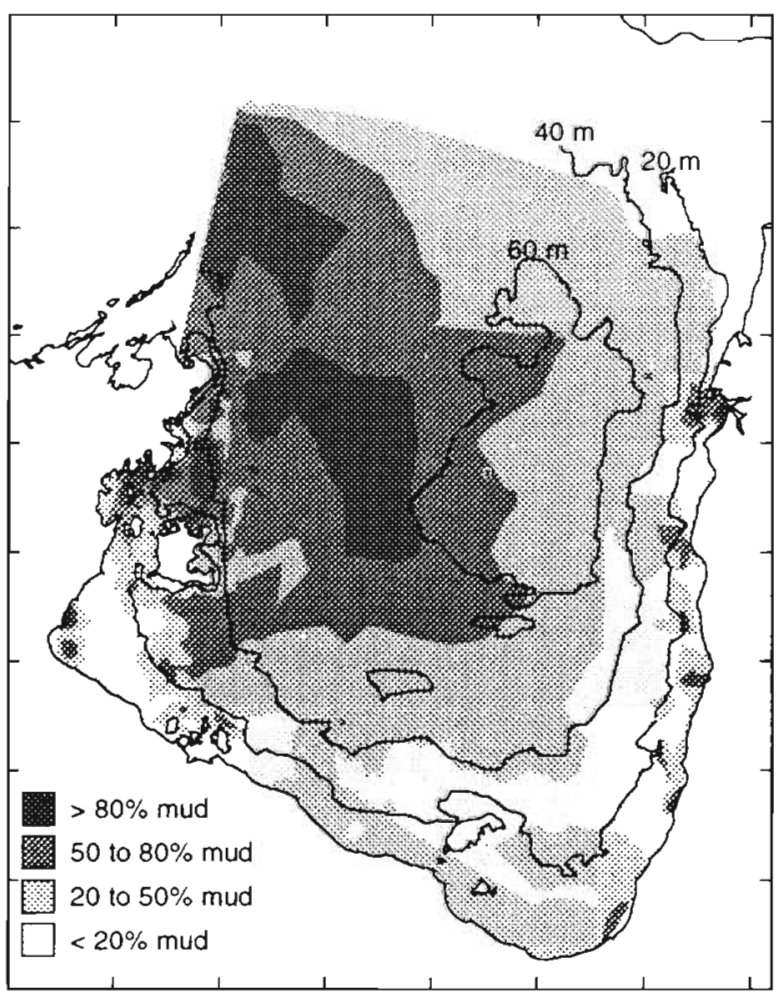

Fig. 3. Sediment grain size, expressed as percent mud grouped into 4 categories, present throughout the Gulf of Carpentaria, Australia, during November-December 1990. Depth contours (m) overlaid. Map adapted from Somers \& Long (in press)

square-root transformed, to normalise the data (Sokal \& Rohlf 1981).

The sediments in the Gulf graded from sands and muddy sands along the eastern and southern margins to increasingly muddy sediments in the central and northwest (Fig. 3) (Somers \& Long in press). In preliminary analyses, sediment grain size was highly correlated with depth and organic carbon. At the same time there were significant correlations between pigments, depth and organic carbon. Therefore the effect of grain size was removed from all subsequent correlations by using partial correlation analysis (Sokal \& Rohlf 1981).

Long \& Poiner (in press) found that the macrobenthos in the Gulf was numerically dominated by polychaetes and crustaceans ( 47 and $32 \%$ respectively); molluscs and echinoderms were less prevalent $(7$ and $5 \%$ ). Ophiuroids (68\%) were the dominant echinoderms. Deposit feeders and scavengers were the numerically dominant trophic groups in the macrobenthos. On this basis, correlations between these groups and pigments, organic carbon and environmental parameters were examined. The abundance of macrobenthos was highly correlated with biomass, therefore only abundance was used in the correlation analyses. 


\section{RESULTS}

Chlorophyll a, indicative of the presence of autotrophic benthic algae, undegraded detrital phytoplankton and faecal pellets, was detected at 46 of the 105 sites (Fig. 4a). Concentrations ranged from 5 to $700 \mu \mathrm{g} \mathrm{kg}^{-1}$. The chlorophyll a concentration at most sites was less than $100 \mu \mathrm{g} \mathrm{kg}^{-1}$. The areas of highest concentration (100 to $700 \mu \mathrm{g} \mathrm{kg}^{-1}$ ) were in shallower waters in the southeast, northeast and western Gulf.

As well as chlorophyll $a$, another algal pigment, fucoxanthin, was detected. Fucoxanthin, the indicator pigment for diatoms, chrysophytes and prymnesiophytes ranged in concentration from 4 to $650 \mathrm{\mu g} \mathrm{kg}^{-1}$
Table 1. Correlation matrix between sediment pigments and environmental variables, Gulf of Carpentaria, Australia. Chl $a$ = chlorophyll $a_{i}$ Fuco. = fucoxanthin; Astax. = astaxan thin; Org. $\mathrm{C}=$ organic carbon. The influence of sediment grain size has been removed from the correlation. ${ }^{\prime} \mathrm{r}_{0.01}=$ $0.254: \cdot x_{0.05}=0.195$

\begin{tabular}{|llllll|}
\hline & Chl a & Fuco. & Astax. & Org. C & Depth \\
\hline Chl a & 1.000 & $0.388 \cdots$ & $0.255^{*}$ & 0.104 & $-0.324 \cdots$ \\
Fuco. & & 1.000 & $0.636 \cdots$ & 0.062 & $-0.332 \cdots$ \\
Astax. & & & 1.000 & 0.106 & $-0.277 \cdots$ \\
Org. C & & & & 1.000 & -0.105 \\
Depth & & & & & 1.000 \\
\hline
\end{tabular}
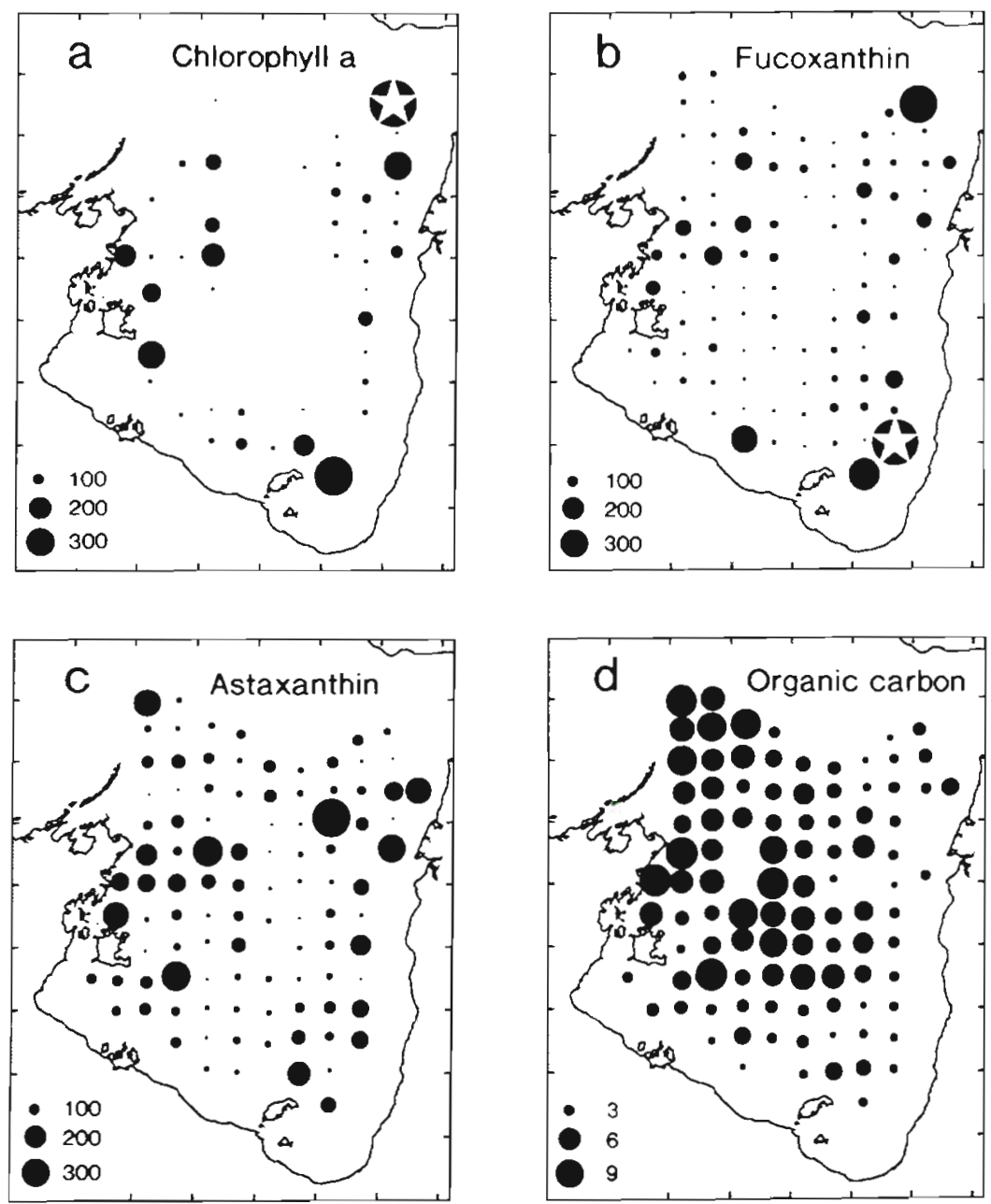

Fig. 4. Concentrations of pigments $\left(\mu \mathrm{g} \mathrm{kg} \mathrm{kg}^{-1}\right)$ and organic carbon $\left(\mathrm{g} \mathrm{kg}^{-1}\right)$ at sites where detected in the Gulf of Carpentaria, Australia, in November-December 1990. Three points along a linear scale are shown in the legend; missing sites denote $0 \mu \mathrm{g} \mathrm{kg}^{-1}$, with the exception of organic carbon where it denotes no sample analysed. (a) Chlorophyll a (microalgae); range $5-700 \mu \mathrm{g} \mathrm{kg}^{-1}$; star denotes $700 \mu \mathrm{g} \mathrm{kg}^{-1}$ (b) Fucoxanthin (diatoms, prymnesiophytes); range $4-650 \mu \mathrm{g} \mathrm{kg}^{-1}$; star denotes $650 \mu \mathrm{g} \mathrm{kg}^{-1}$ (c) Astaxanthin (crustaceans); range $9-400 \mu \mathrm{g} \mathrm{kg}^{-1}$

(d) Organic carbon; range $1-9 \mu \mathrm{g} \mathrm{kg}^{-1}$ and was present at 100 of the 105 sites (Fig. 4b). The highest concentrations were in the southeast, northeast and western areas of the Gulf.

Astaxanthin and its esters, indicative of meiofaunal crustaceans, were detected at 105 sites (Fig. 4c). Its concentration ranged from 9 to $400 \mu \mathrm{g} \mathrm{kg}^{-1}$ with areas of highest concentration in the eastern and western Gulf.

Organic carbon values in the sediment ranged from 1 to $9 \mathrm{~g} \mathrm{~kg}^{-1}$ (Fig. 4d). The northwest and central Gulf were the areas of highest concentration and decreased towards the southeast. This is in contrast to the pigments which were predominantly in the northeast, southeast and west.

Correlations between pigments were significant even after the variation due to sediment grain size was statistically controlled. Chlorophyll a correlated with fucoxanthin and astaxanthin while fucoxanthin correlated with astaxanthin (Table 1). All the pigments were inversely correlated with deptn.

Chlorophyll a was significantly correlated with mollusc abundance (Table 2). Fucoxanthin correlated with the abundance of polychaetes, molluscs, crustaceans, suspensionfeeders and scavengers. Astaxanthin was not highly correlated with the macrobenthos

Organic carbon was not correlated with pigments (Table 1). It was highly correlated with the macrobenthos, with the exception of ophiuroids; 


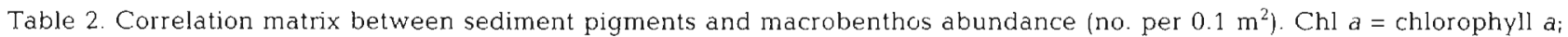
Fuco $=$ fucoxanthin; Astax. $=$ astaxanthin; Org. $\mathrm{C}=$ organic carbon. ${ }^{*} \mathrm{r}_{0.01}=0.254 ;{ }^{*} \mathrm{r}_{0.05}=0.195$. The influence of sediment grain size has been removed from the correlation. Correlations in parentheses have sediment grain size included

\begin{tabular}{|c|c|c|c|c|c|c|c|}
\hline \multirow[b]{2}{*}{ Macrobenthos } & \multirow{2}{*}{$\begin{array}{l}\text { Chl a } \\
0.202^{*}\end{array}$} & \multirow{2}{*}{$\begin{array}{l}\text { Fuco. } \\
0.461 \cdots\end{array}$} & \multirow{2}{*}{$\begin{array}{l}\text { Astax. } \\
0.182\end{array}$} & \multicolumn{2}{|c|}{ Org. C } & \multicolumn{2}{|c|}{ Depth } \\
\hline & & & & -0.093 & $\left(-0.635^{\cdots}\right)$ & $0.323^{\cdots}$ & $(0.492 \cdots)$ \\
\hline Polychaeta & 0.026 & $0.319^{\cdots}$ & 0.152 & -0.064 & $(-0.612 \cdots)$ & $0.204^{\circ}$ & $\left(0.403^{\cdots}\right)$ \\
\hline Mollusca & $0.451^{\cdots}$ & $0.341^{\cdots}$ & 0.051 & 0.121 & $\left(-0.320^{\cdots}\right)$ & 0.193 & $(0.363 \cdots)$ \\
\hline Ophiuroidea & 0.148 & $0.194^{\circ}$ & $0.190^{\circ}$ & 0.019 & $(-0.111)$ & $0.267^{\cdots}$ & $\left(0.367^{\cdots}\right)$ \\
\hline Crustacea & 0.025 & $0.289 \cdots$ & 0.112 & $-0.207^{\circ}$ & $(-0.534 \cdots)$ & 0.150 & $\left(0.310^{\cdots}\right)$ \\
\hline Deposit feeders & 0.020 & $0.225^{\circ}$ & $0.212^{*}$ & $-0.226^{\bullet}$ & $\left(-0.528^{\cdots}\right)$ & $0.208^{\circ}$ & $\left(0.391^{\cdots}\right)$ \\
\hline Suspension feeders & $0.232^{\circ}$ & $0.431^{\cdots}$ & 0.010 & -0.054 & $(-0.533 \cdots)$ & 0.153 & $\left(0.351^{\cdots}\right)$ \\
\hline Scavengers & 0.120 & $0.393^{\cdots}$ & 0.163 & 0.023 & $\left(-0.618^{\cdots}\right)$ & $0.304^{\cdots}$ & $\left(0.475^{\cdots}\right)$ \\
\hline
\end{tabular}

however, with sediment grain size statistically controlled through partial correlation analysis, organic carbon did not correlate highly with any parameters (Table 2). Depth was also highly correlated with the macrobenthos; however, with sediment grain size removed from the correlation matrix, it was only highly correlated with the macrobenthos, and specifically with ophiuroid and scavenger abundance.

\section{DISCUSSION}

The chlorophyll a concentrations in sediment throughout the Gulf of Carpentaria in November (spring) were lower ( 0 to $700 \mu \mathrm{g} \mathrm{kg}^{-1}$ ) than at other shallow tropical sites (Bunt et al. 1972, Plante-Cuny 1978, Alongi 1989). On the Great Barrier Reef continental shelf, Alongi (1989) found chlorophyll a concentrations ranged from 100 to $2000 \mu \mathrm{g} \mathrm{kg}^{-1}$, with no variation between spring and summer. Bunt et al. (1972) found concentrations of 1500 to $6200 \mu \mathrm{g} \mathrm{kg}^{-1}$ in calcareous sediments in the Caribbean Sea and off the coast of Florida (USA) in summer and autumn. In a study off the coast of Madagascar, concentrations of 100 to $1900 \mu \mathrm{g} \mathrm{kg}^{-1}$ were detected in sandy sediment (Plante-Cuny 1978).

Although the chlorophyll a concentrations throughout the Gulf were generally low, there were 3 areas of highest concentration, the southeast corner, northeast and western regions. These concentrations were an order of magnitude higher than the other regions of the Gulf. Coinciding with the high chlorophyll a concentrations in the northwest were high phytoplankton biomasses and productivities relative to the central Gulf (Rothlisberg et al. in press). There is also a potential for tidal mixing in the eastern coastal regions (Forbes 1984), which would result in sustained nutrient inputs and hence a potential increase in algal productivity and biomass. The high chlorophyll concentrations in the southeast corner of the Gulf coincide with seasonal riverine inputs which provide a source of nutrients. Phytoplankton biomass and productivity were also high in this region (Rothlisberg et al. in press). The high chlorophyll a concentrations in the western region of the Gulf occur in a region with muddy sediments and high organic carbon values. Other studies have shown a link between chlorophyll $a$, sediment type and organic carbon (Shaffer \& Onuf 1983, Basford \& Eleftheriou 1988, Fielding et al. 1988).

Algal pigments found in or on the sediment surface are derived from resident benthic algae, detrital phytoplankton and faecal pellets from the zooplankton. They are a reflection of a number of different processes: growth of algal cells, degradation of senescent algal cells under the influence of chemical oxidation, and degradation of algal cells present in faecal pellets. The low concentrations of sediment chlorophyll a suggest a low biomass of benthic microalgae. In addition, they may indicate either a low biomass of phytoplankton detritus settling from overlying waters or a rapid degradation of detritus. Concentrations of chlorophyll $a$ in the water column are not low (mean $=29 \mathrm{mg} \mathrm{m}^{-2}$ ) in comparison to those of other tropical continental shelf regions (Motoda et al. 1978, Hallegraeff \& Jeffrey 1984, Rothlisberg et al. in press). Highest concentrations, in waters deeper than $20 \mathrm{~m}$, were $1 \mathrm{mg} \mathrm{m}^{-3}$ (Rothlisberg et al. in press). The chlorophyll a maxima were generally in the bottom $10 \mathrm{~m}$ of the water column whereas the biomass-specific primary productivity was at mid-depth. Given these results, the light availability at the sediment surface throughout the Gulf of Carpentaria would be low. This is reflected in the low chlorophyll a concentrations in the sediment. The low biomass in the sediment therefore suggests that there is a relatively lage amount of phytoplankton detritus which is rapidly degrading in the sediment. In a 2 yr study of plankton in the Gulf of Carpentaria, Rothlisberg \& Jackson (1982) found consistently high bio- 
masses in comparison with other sites around Australia. A high rate of consumption of phytoplankton detritus could also, therefore, be occurring.

In our study, fucoxanthin, the indicator pigment for diatoms, prymesiophytes and chrysophytes, was present in the sediment throughout the Gulf and was correlated with chlorophyll a. Fucoxanthin was more widespread than chlorophyll $a$, occurring at 100 sites compared with chlorophyll a which occurred at 46 of the 105 sites. This suggests that the fucoxanthin was of detrital rather than benthic origin. Hallegraeff \& Jeffrey (1984) found that diatoms were the dominant algal group in the waters of the Gulf of Carpentaria in March 1982. Rothlisberg et al. (in press) indicate that in February 1988, prymnesiophytes and diatoms were the dominant groups at most sites sampled throughout the Gulf. Everitt et al. (1990), in studies on diatomdominated phytoplankton in tropical waters, determined a ratio of chlorophyll a to fucoxanthin of 1.4 . When the ratio of chlorophyll a to fucoxanthin in the sediment in the Gulf of Carpentaria is calculated, a mean value of 0.35 is obtained. This ratio is higher than would be expected from a diatom-dominated benthic community and again suggests a high contribution by diatoms in the phytoplankton detritus.

Fucoxanthin and chlorophyll $a$ are both short-lived markers due to their rapid degradation in phytoplankton detritus (Ridout \& Morris 1988, Abele-Oeschger 1991). They, therefore, only reflect recent phytoplankton sedimentation events. Little information is available on the rates of breakdown of these pigments in marine systems with the exception of faecal pellets (Nelson 1989, Head \& Harris 1992). However, degradation rates have been shown to vary depending on light and oxygen conditions (Leavitt 1988, AbeleOeschger 1991).

The presence of astaxanthin and its esters in the Gulf of Carpentaria sediments indicates that microcrustaceans are a component of the meiofaunal benthic community. Long \& Poiner (in press) did not quantify the meiofauna when examining the macrobenthos (>1 mm sieve) and it appears that this meiofaunal community warrants further examination.

Organic carbon concentrations in the Gulf of Carpentaria ranged from 1 to $9 \mathrm{~g} \mathrm{~kg}^{-1}$. Concentrations in the central Great Barrier Reef continental shelf of 4 to $6 \mathrm{~g} \mathrm{~kg}^{-1}$ were comparable (Alongi 1989). In a study in the western Gulf of Carpentaria, Somers (1987) found relatively high concentrations of organic carbon (8.6 to $21.2 \mathrm{~g} \mathrm{~kg}^{-1}$ ) which correlated with the mud content of the sediment. The correlation between organic carbon concentration and sediment type in the Gulf of Carpentaria has also been found in other study sites throughout the world (e.g. Basford \& Eleftheriou 1988, Alongi 1990). In our study, organic carbon was not cor- related with macrobenthos or pigments in the absence of sediment type. Therefore, the influence of sediment type should be statistically removed from correlations of benthic parameters if organic carbon is to be a more accurate measure of the food available to the benthic community.

The correlations between macrobenthos, pigments and depth suggest that phytoplankton detritus may be providing a food source for the macrobenthos. Long \& Poiner (in press) have shown that deposit feeders, capable of consuming the phytoplankton, were dominant throughout the Gulf. Few herbivores were found. However, these correlations only explained up to $10 \%$ of the variation and it is clear that other variables are influencing the distribution of both pigments and macrobenthos. Heip et al. (1992) found a significant correlation (5\%) between benthic macrofauna and chlorophyll $a$ in sediment in the North Sea, indicating that microalgae are an important food source.

The low chlor ophyll a concentrations in the sediment contrasted with the abundance of macrobenthos, which were comparable with other tropical shelf areas (Long \& Poiner in press). The overall productivity in the water column of the Gulf, namely phytoplankton, plankton and fish, is generally comparable to or slightly higher than that in other tropical regions (Rothlisberg \& Jackson 1982, Blaber et al. in press, Rothlisberg et al. in press). It therefore appears that the low concentrations of chlorophyll $a$ in the sediment reflect rapid degradation of phytoplankton detritus, either in the water column or the sediment.

In conclusion, the generally low concentrations of chlorophyll $a$ in the sediment are a reflection of a low biomass of benthic algae. Diatoms, prymnesiophytes and chrysophytes, in the form of phytoplankton detritus, were a significant component of the microalgal biomass in the sediment. The correlations between pigments and macrobenthos suggest that phytoplankton detritus is providing a food source for detritus feeders. Organic carbon was a poor indicator of biological factors because it was highly correlated with sediment grain size. Based on this single cruise it is clear that continued work, on a seasonal basis, will have to focus on both the water column and the sediment to understand the trophodynamics underpinning the benthic community and the fisheries that rely on them.

Acknowledgements. We thank the Captain and crew of the FRV 'Southern Surveyor' for assistance at sea. James Smith assisted with the benthic sampling. Frances D'Souza and Mark O'Donohue analysed the pigment and organic carbon samples. Ian Poiner, Steve Blaber and Vivienne Mawson constructively criticised early drafts of this manuscript. This work was supported by a Fishing Industry Research and Development Trust Account grant (FIRDTA 88/77). 


\section{LITERATURE CITED}

Abele-Oeschger, D. (1991), Potential of some carotenoids in two recent sediments of Kiel Bight as biogenic indicators of phytodetritus. Mar. Ecol. Prog. Ser 70: 83-92

Alongi, D. M. (1989), Benthic processes across mixed terrigenous-carbonate sedimentary facies on the central Great Barrier Reef continental shelf. Cont. Shelf Res. 9: 629-663

Alongi, D. M. (1990). The ecology of tropical soft-bottom benthic ecosystems. Oceanogr. mar. Biol. A. Rev. 28: 318-496

Basford, D., Eleftheriou, A. (1988). The benthic environment of the North Sea $\left(56^{\circ}\right.$ to $61^{\circ}$ N). J. mar. biol. Ass. U.K. 68: $125-141$

Blaber, S. J. M., Brewer, D. T., Harris, A. N. (in press). The distribution, biomass and community structure of fishes of the Gulf of Carpentaria. Aust. J. mar. Freshwat. Res.

Bunt, J. S., Lee, C. C., Lee, E. (1972). Primary productivity and related data from tropical and subtropical marine sediments. Mar. Biol. 16: 28-36

Castillo, R., Negres-Sadargues, G., Lenel, R. (1982). General survey of carotenoids in crustaceans. In: Britton, G., Goodwin, $T$. (eds.) Carotenoid chemistry and biochemistry. Oxford University Press, London, p. 221-224

Daemen, E. A. M. J. (1986). Comparison of methods for the determination of chlorophyll in estuarine sediments. Neth. J. Sea Res. 20: 21-28

Everitt, D. A., Wright, S. W., Volkman, J. K., Thomas, D. P., Lindstrom, E. J. (1990). Phytoplankton community compositions in the western equatorial Pacific determined from chlorophyll and carotenoid pigment distributions. Deep Sea Res. 37: 975-997

Fielding, P. J., Damstra, K. St. J., Branch, G. M. (1988). Benthic diatom biomass, production and sediment chlorophyll in Langebaan Lagoon, South Africa. Estuar. coast. Shelf Sci. 27: 413-426

Forbes, A. M. G. (1984). The contribution of local processes to seasonal hydrology of the Gulf of Carpentaria. Océanogr. trop. 19: 193-201

Gaudette, H. E., Flight, W. R., Toner, L., Folger, D. W. (1974). An inexpensive method for the determination of organic carbon in recent sediments. J. sedim. Petrol, 44: 249-253

Gieskes, W. W. C., Kraay, G. W. (1983). Dominance of Cryptophyceae during the phytoplankton spring bloom in the central North Sea detected by HPLC analysis of pigments. Mar. Biol. 75: 179-185

Gieskes, W. W. C., Kraay, G. W., Nontji, A., Setiapermana, D. Sumoto (1988). Monsoonal alternation of a mixed and a layered structure in the phytoplankton of the euphotic zone of the Banda Sea (Indonesia): mathematical analysis of algal pigment fingerprints. Neth. J. Sea Res. 22: $123-137$

Hallegraeff, G. M., Jeffrey, S. W. (1984). Tropical phytoplankton species and pigments of continental shelf waters of North and North-West Australia. Mar. Ecol. Prog. Ser. 20: $59-74$

Head, E. J. H., Harris, L. R. (1992). Chlorophyll and carotenoid transformation and destruction by Calanus spp. grazing on diatoms. Mar. Ecol. Prog. Ser. 86: 229-238

Heip, C., Basford, D., Craeymeersch, J. A., Dewarumez, J.-M., Dörjes, J., de Wilde, P., Duineveld, G., Eleftheriou,

This article was submitted to the editor
A., Herman, P. M. J., Niermann, U., Kingston, P., Kunitzer A., Rachor, E., Rumohr, H., Soetaert, K., Soltwedel, T (1992). Trends in biomass, density and diversity of North Sea macrofauna. ICES J. mar. Sci. 49: 13-22

Leavitt, P. R. (1988). Experimental determination of carotenoid degradation. J. Paleolimnol. 1.215-227

Long, B. G., Poiner, I. R. (in press). Infaunal benthic community structure and function in the Gulf of Carpentaria, Northern Australia. Aust. J. mar. Freshwat. Res.

Motoda, S., Kawamura, T., Taniguchi, A. (1978). Differences in productivities between the Great Australian Bight and the Gulf of Carpentaria, Australia, in summer. Mar. Biol. 46: 93-99

Nelson, J. R. (1989). Phytoplankton pigments in macrozooplankton feces: variability in carotenoid alterations. Mar Ecol. Prog. Ser. 52: 129-144

Plante-Cuny, M.-R. (1978). Pigments photosynthétiques et production primaire des fonds meubles néritiques d'une région tropicale (Nosy-Bé, Madagascar). Trav. Doc. ORSTOM 96: 1-359

Repeta, D. J., Gagosian, R. B. (1987). Carotenoid diagenesis in recent marine sediments - I. The Peru continental shelf (15PS, 75PW). Geochim. Cosmochim. Acta 51: 1001-1009

Ridout, P. S., Morris, R. J. (1988). Further studies of short-term variation in the pigments composition of a spring phytoplankton bloom. Mar. Biol. 97: 597-602

Rothlisberg, P. C., Jackson, C. J. (1982). Temporal and spatial variation of plankton abundance in the Gulf of Carpentaria, Australia 1975-1977. J. Plankton Res. 4: 19-40

Rothlisberg, P. C., Pollard, P. C., Nichols, P. D., Moriarty, D. J. W., Forbes, A. M. G., Jackson, C. J., Vaudrey, D. (in press). Phytoplankton community structure and productivity in relation to the hydrological regime of the Gulf of Carpentaria in summer. Aust. J. mar. Freshwat. Res.

Rowan. K. S. (1989). Photosynthetic pigments of algae. Cambridge University Press, Cambridge

Shaffer, G. P., Onuf, C. P. (1983). An analysis of factors influencing the primary production of the benthic microflora in a southern California Lagoon. Neth. J. Sea Res. 17 : $126-144$

Sokal, R. R., Rohlf, F. J. (1981). Biometry. The principles and practices of statistics in biological research, 2nd edn. W. H. Freeman and Co., New York

Somers, I. F. (1987). Sediment type as a factor in the distribution of commercial prawn species in the western Gulf of Carpentaria, Australia. Aust. J. mar. Freshwat. Res. 38: $133-149$

Somers, I. F. Long, B. G. (in press). A note on the sediments and hydrology of the Gulf of Carpentaria, Australia. Aust. J. mar. Freshwat. Res.

Stauber, J. L., Jeffrey, S. W. (1988). Photosynthetic pigments in fifty-one species of marine diatoms. J. Phycol. 24: $158-172$

Wright, S. W., Jeffrey, S. W. (1987). Fucoxanthin pigment markers of marine phytoplankton analysed by HPLC and HPTLC. Mar. Ecol. Prog. Ser. 38: 259-266

Wright, S. W., Shearer, J. D. (1984). Rapid extraction and high performance liquid chromatography of chlorophylls and carotenoids from marine phytoplankton. J. Chromatogr. 294: $281-295$

Manuscript first received: May 18, 1993

Revised version accepted: August 25, 1993 